\title{
The Fed, Liquidity, and Credit Allocation
}

\author{
Daniel L. Thornton
}

The current financial turmoil has generated considerable discussion of liquidity. Moreover, it has been widely reported that the Federal Reserve played a major role in supplying liquidity to financial markets during this distressed time. This article describes two ways in which the Fed has supplied liquidity since late 2007. The first is traditional: The Fed supplies liquidity by providing credit through open market operations and by lending to depository institutions at the so-called discount window. The second is by enhancing the liquidity of portfolios of some institutions by replacing their less-liquid assets with more-liquid assets. The Fed has used the second approach since late 2007. Unlike several previous occasions, however, it began supplying liquidity in the first, more traditional way only recently-in September 2008. This article notes that the Fed departed from its long-standing tradition of minimizing its effect on the allocation of credit by supplying liquidity to institutions that it believed to be most in need; at the same time, it neutralized the effects of these actions on the total supply of liquidity in the financial market. The article also discusses the Fed's reasons for reallocating credit this time rather than simply increasing the total supply of financial market liquidity. (JEL E44, E52, E58)

Federal Reserve Bank of St. Louis Review, January/February 2009, 91(1), pp. 13-21.

\section{ASSET LIQUIDITY AND FINANCIAL MARKET LIQUIDITY}

$\checkmark$

nfortunately, the word "liquidity" is

often used to describe very different things. Liquidity is perhaps most often used to describe a particular characteristic of an asset. In this sense, liquidity means the "degree of ease and certainty of value with which a security can be converted into cash." Cash is pure liquidity. Every other asset has a degree of liquidity that is determined by (i) how quickly it can be converted to cash and (ii) how much the price of the asset must be reduced to do so. The second requirement stems from the fact that virtually any asset can be converted to cash quickly if the price is sufficiently attractive.
The word "liquidity" is also used to describe the availability of credit in the financial market. For example, market analysts or policymakers might say there is a shortage of liquidity in the market or that the financial market is "frozen up." This means that it is difficult or expensive to obtain a loan (i.e., get credit). Like the liquidity of an asset, this concept of market liquidity is relative. Even in the most liquid of financial markets, some individuals or firms will be unable to obtain a loan or, if they do, they will be charged a relatively high interest rate. Likewise, many individuals or institutions obtain credit in markets described as "illiquid." No absolute measure of the liquidity of the financial market exists.

An important distinction separates the concept of market liquidity from the concept of asset

Daniel L. Thornton is a vice president and economic adviser at the Federal Reserve Bank of St. Louis. The author thanks Aditya Gummadavelli and Mary Karr for research assistance.

(C) 2009, The Federal Reserve Bank of St. Louis. The views expressed in this article are those of the author(s) and do not necessarily reflect the views of the Federal Reserve System, the Board of Governors, or the regional Federal Reserve Banks. Articles may be reprinted, reproduced, published, distributed, displayed, and transmitted in their entirety if copyright notice, author name(s), and full citation are included. Abstracts, synopses, and other derivative works may be made only with prior written permission of the Federal Reserve Bank of St. Louis. 


\section{Thornton}

liquidity. By the latter definition, cash is the quintessence of liquidity; however, "a shortage of liquidity" in the financial market does not mean a shortage of cash because there can never be a shortage of cash. This was not always the case. Before the establishment of the Federal Reserve, shortages of cash did occur. However, when the Federal Reserve was established, it was designed to provide an "elastic currency." That is, it was designed so that the quantity of cash automatically increases to meet society's demand for it: Thus, there can never be a shortage of cash. When market analysts and others say that the market has become less liquid or is illiquid, they mean that it is more difficult to get a loan than before; they do not mean there is a shortage of cash.

\section{THE FED AS A SUPPLIER OF MARKET LIQUIDITY}

Fundamentally, domestic credit has three major sources: private saving (individuals and firms), government saving (surpluses of federal, state, and local governments), and changes in the monetary base- the sum of cash held by the public and bank reserves. The Fed supplies the market with credit through open market operations and, to a much lesser extent historically, through loans to depository institutions at the discount window. These actions increase the total supply of credit in the financial market. This is most easily seen in Fed lending at the discount window. When the Fed makes a loan at the discount window, it is directly extending credit to the borrowing institution. That is, the Fed takes the IOU of the borrowing institution in return for funds-specifically, deposit balances at the Fed.

The effect of an open market purchase of securities on the total supply of credit is exactly the same as an equal amount of lending at the discount window. In this case, the Fed acquires a security (i.e., an IOU) in exchange for fundsdeposit balances at the Fed. Historically, the Fed has conducted open market operations in government and agency securities; however, open market operations can be carried out in any asset prescribed by the Federal Reserve Act. When the Fed purchases Treasury securities from the public, it is indirectly making the loan to the Treasury rather than the public. Hence, the supply of credit available to the public increases. ${ }^{1}$ Of course, if the Fed sells some of its securities, the supply of credit available to the public declines. All other things equal, the supply of credit in the financial market increases or decreases as the monetary base increases or decreases, regardless of whether the change in the monetary base is due to Fed lending or open market operations.

\section{THE FED AND THE ALLOCATION OF CREDIT}

Although lending by the Fed has exactly the same effect on the monetary base as an equivalent open market operation, the effect of these actions on the allocation of credit is different. When the Fed makes a loan to a depository institution, or anyone else, it directly allocates credit to that institution. The effect on the allocation of credit is mitigated by the fact that the total supply of credit increases-the borrowing institution obtains credit and no one loses credit. The effect of Fed lending on the allocation of credit is intensified when the Fed offsets the effect of its lending activity on the total supply of credit through open market operations. In this case, the borrowing institution obtains credit but the total supply of credit is unchanged. In effect, the borrowing institution is getting credit at the expense of some other individual or institution: The total supply of credit is reallocated.

Historically, the Fed has offset the effect of discount window lending on the total supply of credit through open market operations. ${ }^{2}$ That is, if depository institutions borrowed at the discount window, the Fed would offset the effect of this increased borrowing on the monetary base by selling a comparable amount of securities in an open market operation.

\footnotetext{
1 This example is used for ease of understanding. The effect is the same regardless of what the Fed purchases.

2 For a dramatic example that had important implications for monetary policy analyses, see Thornton (2001).
} 
The practice of offsetting the effect of discount window lending on the monetary base means that discount window lending reallocated credit to the borrowing institution. The effect of discount window lending on credit allocation has not been an issue for two reasons. First, the initial effect of an open market operation is on depository institutions. Consequently, a discount window loan to a depository institution that is offset through open market operations has the effect of reallocating credit among depository institutions.

Second, and more important, discount window lending has been small historically. For much of its history, the Fed has discouraged depository institutions from borrowing at the discount window. Depository institutions were expected to come to the window only when they had exhausted the relevant alternative sources of funds. In addition, following the substantial borrowing by thentroubled Continental Illinois Bank in May 1984, depository institutions grew increasingly reluctant to borrow from the Fed because of concern that such borrowing institutions would be perceived as "troubled." 3

For these reasons discount window borrowing has been small historically. For example, from January 1985 though December 2007, discount window borrowing averaged \$547 million-less than two-tenths of 1 percent of the monetary base. Consequently, borrowing has had little effect on the allocation of credit in the financial market. Moreover, because of the Fed's practice of offsetting the effect of borrowing, discount window borrowing has had little effect on the monetary base. The correlation between discount window borrowing and changes in the monetary base from January 1985 through August 2008 was essentially zero (less than 1 percent).

The insignificant effect of such borrowing on the allocation of credit in the financial market is consistent with the Fed's long-standing practice of minimal interference in the government securities market in particular and the credit market more generally. The Fed traditionally has conducted open market operations at the very short

\footnotetext{
3 See Thornton (2001) for a discussion of the effects from the Continental Illinois Bank experience on discount window borrowing.
}

end of the maturity structure and primarily in Treasury securities to minimize the effect of its operations on the structure of interest rates. With the exception of a short departure in the early 1960s, this policy has guided the conduct of open market operations. ${ }^{4}$

\section{THE FED'S NEW LENDING FACILITIES AND THE ALLOCATION OF CREDIT}

In response to the distress in financial markets associated with the decline in house prices, the Fed initiated a series of new lending programs that according to Cecchetti (2008) were implemented to ensure "that liquidity would be distributed to those institutions that needed it most."5 First among these programs was the Term Auction Facility (TAF), by which the Fed auctions funds to depository institutions. The TAF differs from normal discount window borrowing in two respects. First, rather than coming to the Fed to request a discount window loan, under the TAF the Fed auctions a predetermined amount of funds. Second, rather than paying the "primary credit rate" (formerly known as the discount rate), depository institutions that borrow under the TAF pay the "stop-out rate"- the lowest bid rate that exhausts the funds being auctioned. ${ }^{6}$ It was hoped that the TAF's alternative method of borrowing would counter depository institutions' reluctance to borrow from the Fed. Once depository institutions became comfortable with borrowing from the Fed, the stigma associated with discount window borrowing would be reduced. This appears to have happened. Primary credit borrowing averaged $\$ 11.85$ billion during the first nine months of 2008. However, Thornton (2008) shows that depository institutions borrow at the discount

\footnotetext{
4 For discussions of this so-called bills-only policy, see Friedman and Schwartz (1963) and Meltzer (2009). The classic article on the Fed's brief deviation from this policy, called "Operation Twist," is by Modigliani and Sutch (1966).

5 Cecchetti (2008, abstract).

6 The Fed establishes a minimum bid rate at which it will lend. Loans are made at the minimum bid rate only when the demand for loans at this rate is less than or equal to the amount being auctioned.
} 


\section{Figure 1}

\section{Monetary Base (January 1995-November 2008)}

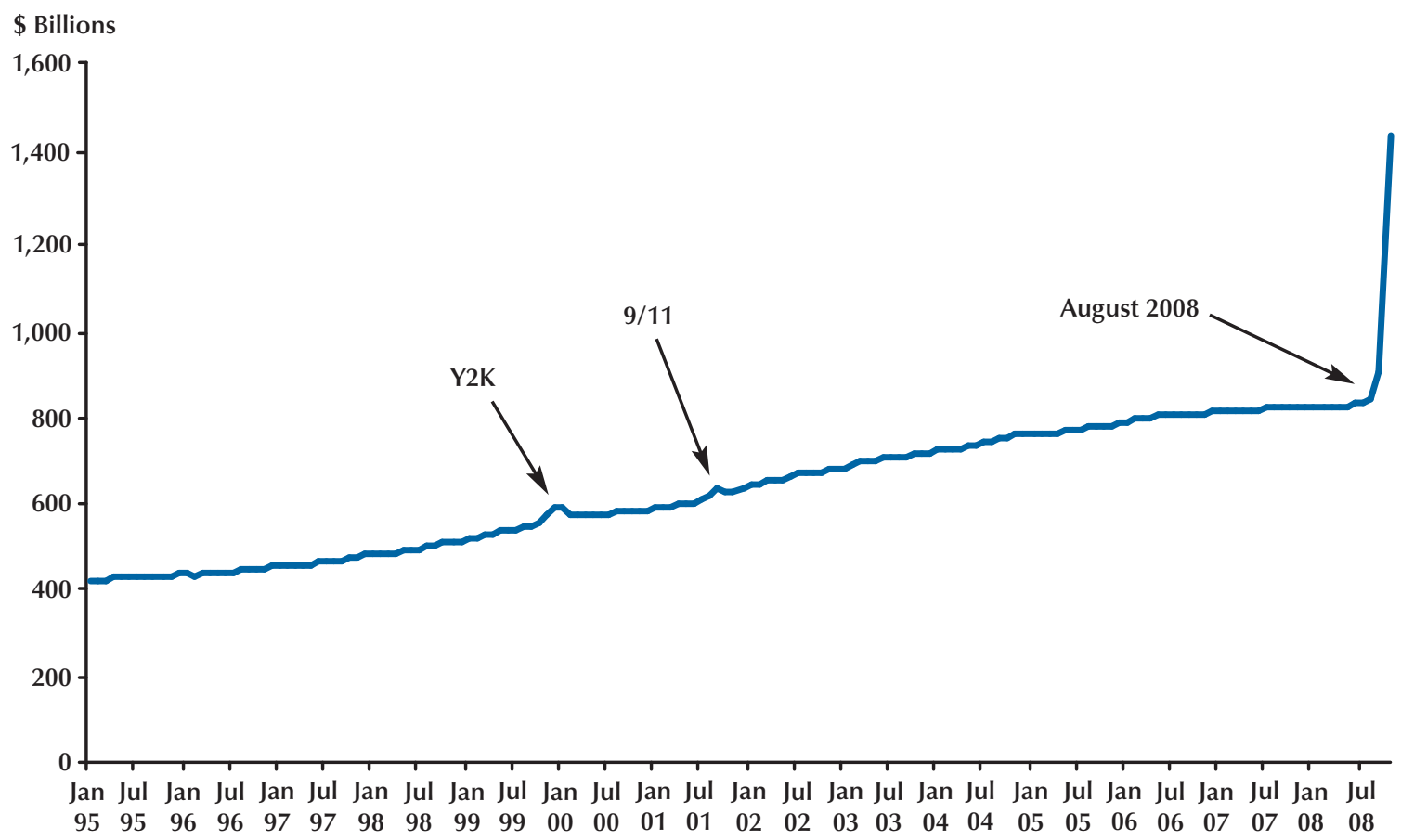

window only when the primary credit rate is lower than the rates on alternative sources of funds.

The Fed subsequently initiated several additional lending facilities. The Primary Dealer Credit Facility (PDCF) essentially opened the discount window to primary government security dealers. ${ }^{7}$ The Asset-Backed Commercial Paper Money Market Mutual Fund Liquidity Facility (ABCP MMMF Liquidity Facility) is intended to increase liquidity in the commercial paper market by providing loans to U.S. depository institutions and bank holding companies for the purpose of purchasing high-quality asset-backed commercial paper. ${ }^{8}$

Under the TAF, the PDCF and, most recently, the ABCP MMMF Liquidity Facility, the Fed is

${ }^{7}$ For a list of these dealers, access

www.newyorkfed.org/markets/pridealers_current.html.

8 There are several other lending facilities not discussed here. For more information on these new lending facilities established before essentially making loans to the participating institutions. All other things equal, such loans increase the monetary base. Until mid-September 2008, the Fed offset the effect of these lending programs on the total supply of credit through open market operations. Figure 1 shows the level of the monetary base from January 1995 through November 2008. The figure shows that the hundreds of billions of dollars of "liquidity" supplied through these facilities had no impact on the monetary base and, consequently, no effect on the total supply of credit in the financial market until September 2008.

The Fed's behavior of not increasing the total supply of credit when there were liquidity concerns differs markedly from its response to liquid-

May 2008, see Cecchetti (2008). For information on all of the new lending facilities, visit the websites of the Federal Reserve Bank of New York or the Board of Governors of the Federal Reserve System. These new lending facilities are temporary; however, there has been some discussion about making the TAF permanent. 
ity concerns on two previous occasions. Figure 1 shows two prior occasions when the monetary base increased sharply. The first occurred in late 1999 and was associated with Y2K-that is, widespread concerns about computer failures associated with the century date change. Such worries included beliefs that Y2K changes might significantly reduce the liquidity of the financial market. To guard against this possibility, the Fed injected relatively large amounts of base money (i.e., credit) through open market operations. The Y2K concerns never materialized. With no need for additional liquidity, the Fed quickly drained the base money it had supplied in anticipation of a liquidity shortage, and the monetary base resumed its normal growth path.

The second instance of liquidity influx by the Fed was associated with the terrorist attacks on September 11, 2001. Financial institutions that occupied the World Trade Center played an important role in U.S. financial markets. The terrorist attack on the World Trade Center significantly impeded the operations of these institutions and, importantly, their ability to provide credit. Recog nizing this liquidity shortage, the Fed responded quickly and increased the monetary base by well over $\$ 100$ billion. The affected firms were able to resume more or less normal operations quickly, so the additional base money was only supplied for a few days. ${ }^{9}$

Despite claims that the Fed has been supplying massive amounts of liquidity through its new lending programs, Figure 1 shows that no sharp rise in the monetary base occurred until September 2008; the liquidity supplied by the Fed was being offset through open market operations. Hence, the Fed did not increase the total supply of liquidity to the financial markets, as it did for Y2K or 9/11. These facilities merely increased the liquidity of the participating institutions' balance sheets by allowing participating institutions to exchange less-liquid (or illiquid) assets for highly liquid assets. This is particularly true of the Term Securities Lending Facility (TSLF) through which primary dealers essentially borrow specific Treasury securities

${ }^{9}$ See Neely (2004). offered by the Fed in exchange for less-liquid securities. These loans have no potential to increase the monetary base because they are essentially an exchange of less-liquid assets of the government security dealers for more-liquid Treasury securities held by the Fed.

The Fed's action to offset the effect of this borrowing on the supply of liquidity suggests that these facilities were intended only to increase the liquidity of the participating institutions' balance sheets, without increasing the liquidity of the financial market generally. In so doing, these programs had a significant effect on the allocation of credit by the Fed. As of November 19, 2008, the total amount of loans outstanding under the TAF, the other lending programs, and regular discount window borrowing was $\$ 1,611.5$ billion, whereas the total monetary base was $\$ 1,476.4$ billion. Hence, nearly all of the total credit supplied by the Fed was being allocated directly to participating institutions.

Beginning in September 2008, the Fed increased its total supply of credit to the market. Between August 27, 2008, and November 19, 2008, the monetary base increased by about $\$ 635.2$ billion. Over this same period, Fed lending increased by $\$ 1,308.9$ billion. Hence, the Fed offset the effect on the total supply of credit of 48.5 percent of its additional lending during the period.

\section{CONVENTIONAL VERSUS UNCONVENTIONAL MONETARY POLICY}

The Fed's response to liquidity concerns is a clear departure not only from its actions during Y2K and 9/11, but also from reliance on conventional tools of monetary policy. This current episode raises two interesting questions. Why did the Fed address the liquidity problem by creating a new array of lending programs rather than relying on conventional open market operations and the discount window? And why did the Fed decide to reallocate the total supply of credit rather than increase the total supply of liquidity in the financial market as it did for Y2K and 9/11? 
Cecchetti (2008) suggests that the Fed instituted the new lending programs because it was not confident that it could allocate the credit to the financial institutions most in need of liquidity by using traditional tools. Specifically, he notes that "While well-established mechanisms existed for injecting reserves into a country's financial system, officials had no way to guarantee that the reserves will reach the banks that need them."10

Benanke (2008) appears to confirm Cecchetti's (2008) suggestion. While noting that the European Central Bank (ECB) and the Bank of England responded using conventional tools of monetary policy, Bernanke (2008) observed the following:

In the United States, in ordinary circumstances only depository institutions have direct access to the discount window, and open market operations are conducted with just a small set of primary dealers against a narrow range of highly liquid collateral. In contrast, in jurisdictions with universal banking, the distinction between depository institutions and other types of financial institutions is much less relevant in defining access to central bank liquidity than is the case in the United States. Moreover, some central banks (such as the ECB) have greater flexibility than the Federal Reserve in the types of collateral they can accept in open market operations. As a result, some foreign central banks have been able to address the recent liquidity pressures within their existing frameworks without resorting to extraordinary measures. In contrast, the Federal Reserve has had to use methods it does not usually employ to address liquidity pressures across a number of markets and institutions. In effect, the Federal Reserve has had to innovate in large part to achieve what other central banks have been able to effect through existing tools. that the

Bernanke (2008) continues by suggesting

traditional framework for liquidity provision was not up to addressing the recent strains in short-term funding markets. In particular, the efficacy of the discount window has been limited by the reluctance of depository institutions to use the window as a source of funding.

${ }^{10}$ Cecchetti (2008, p. 15).
The "stigma" associated with the discount window, which if anything intensifies during periods of crisis, arises primarily from banks' concerns that market participants will draw adverse inferences about their financial condition if their borrowing from the Federal Reserve were to become known.

Bernanke's (2008) statement suggests that the Fed was unable to direct the liquidity to institutions most in need using open market operations. However, the Federal Reserve Act (hereafter, Act) does not prevent the Fed from purchasing assetbacked securities, commercial paper, and a wide range of other securities, such as those taken as collateral against loans under the new lending programs. ${ }^{11}$ Nor does the Act prevent the Fed from engaging in open market operations with institutions other than primary security dealers. Although the Fed would have had to modify its open market operating procedures, nothing in the Act per se would have prevented the Fed from using open market operations rather than an array of new lending programs to channel liquidity to institutions or markets most in need of liquidity.

Why the Fed chose not to increase the supply of total liquidity before September 2008 remains unclear. One possibility is that the Fed was concerned that massive injections of liquidity in the financial market would impair its ability to control the federal funds rate. Although he did not specifically state this as the reason, Bernanke (2008) noted that "open market operations have long been the principal tool used by the Federal Reserve to manage the aggregate level of reserves in the banking system and thereby control the federal funds rate."

\footnotetext{
${ }^{11}$ Section 12A of the Act (www.federalreserve.gov/aboutthefed/ section12.htm) created the Federal Open Market Committee (FOMC) and limited the authority of Federal Reserve Banks to undertake open market operations without FOMC direction. Section 14 of the Act (www.federalreserve.gov/aboutthefed/section14.htm) specifies the kinds of "normal course" paper that are used for open market operations. The list is exhaustive (see Small and Clouse, 2005). Open market operations are governed by FOMC rules outlined in 12 CFR 270 (http://ecfr.gpoaccess.gov/cgi/t/text/text-idx?c=ecfr\&tpl=/ ecfrbrowse/Title17/17cfr270_main_02.tpl), which limit the types of securities that the Fed can buy or sell in the normal course of operations. However, Section 270.4(d) of these regulations states that the "Federal Reserve Banks are authorized and directed to engage in such other operations as the Committee may from time to time determine to be reasonably necessary to the effective conduct of open market operations and the effectuation of open market policies."
} 
Another reason may have prompted the Fed's unconventional approach. Benanke (2008) notes that "recent research by Allen and Gale (2007) confirms that, in principle at least, 'fire sales' forced by sharp increases in investors' liquidity preference can drive asset prices below their fundamental value, at a significant cost to the financial system and the economy." Bernanke goes on to say that "A central bank may be able to eliminate, or at least attenuate, adverse outcomes by making cash loans secured by borrowers' illiquid but sound assets."12 Benanke (2008) suggests that in so doing borrowers could avoid selling securities in an illiquid market, which would avoid potential economic damage "arising, for example, from the unavailability of credit for productive purposes or the inefficient liquidation of long-term investments."

\section{THE EFFICACY OF THE NEW APPROACH}

Beyond the question of why the Fed chose this unconventional approach to monetary policy is the question of how effective it is. Many macroeconomists believe that changes in the composition of the Fed's assets that are not accompanied by a change in the monetary base are ineffective. This belief is due, in part, to experience. In the early 1960s, the Fed attempted to reduce longterm interest rates while maintaining relatively high short-term interest rates using a procedure called "Operation Twist." Specifically, the Fed bought long-term securities while simultaneously selling short-term securities, so that the net effect of these transactions on the monetary base was nil. The rationale was that by increasing the demand for long-term securities and reducing the demand for short-term securities, the Fed could "twist" the yield curve-long-term rates would fall relative to short-term rates. Most analysts concluded that the Fed had little or no effect on the shape of the yield curve.

Operation Twist's failure is consistent with alternative theories of the term structure. For

\footnotetext{
${ }^{12}$ Bernanke (2008).
}

example, the expectations hypothesis asserts that long-term rates are determined by the market's expectation of the future short-term rate. If shortterm rates are not expected to fall, then long-term rates will not fall either. The failure of Operation Twist is also consistent with the risk-premium hypothesis, which suggests that rates on longterm securities are generally higher than rates on short-term securities because investors demand a risk premium for investing in longer-term securities because they have a higher degree of market risk. The risk premium is determined by what economists refer to as "deep structural parameters"- that is, the risk aversion of investors. A change in the relative demands for long-term and short-term securities has no effect on the size of the risk premium and, hence, no effect on the shape of the yield curve.

Similar experiences and theoretical arguments apply to attempts to alter the exchange rate through sterilized foreign exchange intervention. Sterilized foreign exchange intervention occurs when a central bank purchases securities denominated in one country's currency and simultaneously sells an equal amount of securities denominated in another country's currency, so the effect on the monetary base is nil. Theory and evidence suggest that foreign sterilized exchange intervention has little or no effect on exchange rates.

Considerable research will be done in the years to come to determine the efficacy of the Fed's new lending programs. Some early work by Taylor and Williams (2008a,b) indicates that the TAF was ineffective in significantly influencing the spread between term LIBOR rates (and other similar rates) and overnight lending rates, which started to rise dramatically in August 2007. Taylor and Williams suggest that the TAF was initiated in part to reduce the spread between term LIBOR rates and overnight lending rates. This motivation is supported by the Fed's February 2008 report to Congress, which states that, "although isolating the impact of the TAF on financial markets is not easy, a decline in spreads in term funding markets since early December provides some evidence that the TAF may have had beneficial effects on 


\section{Thornton}

financial markets" (Board of Governors of the Federal Reserve, 2008).

Taylor and Williams (2008a,b) argue that the rate spread had increased as a result of banks' and other creditors' heightened reluctance to lend to banks perceived to have an increased risk of default. Hence, the rise in term LIBOR rates and other rates that reflect the cost of funds to banks, relative to overnight lending rates, reflects a risk premium that will not be reduced by increasing the liquidity of these banks' portfolios. Taylor and Williams (2008a) conclude that because "the TAF does not affect total liquidity, expectations of future overnight rates, or counterparty risk," it did not affect the rate spread.

\section{CONCLUSION}

In response to the financial turmoil in the wake of declining house prices, the Fed instituted a series of new lending facilities that increased the liquidity of participating institutions' portfolios without simultaneously increasing the total supply of liquidity in the financial market, at least before September 2008. In so doing, the Fed departed significantly from its historical practice of relying on traditional tools of open market operations and discount window lending to provide liquidity to the financial market.

Why the Fed chose to enact a series of new lending programs rather than use its existing tools of open market operations and the discount window is unclear. Given the stigma attached with borrowing from the discount window, the Fed would have had difficulty increasing the supply of total credit by making discount window loans. It could have increased the total supply of credit in the market through open market operations. However, the Federal Open Market Committee (FOMC) would have had to change its operating rules to purchase a broad array of securities, such as those it has taken as collateral under it new lending programs, and to engage in open market operations with entities other than primary security dealers.

It appears, however, that at least initially, the Fed did not want to address the financial market turmoil by increasing the total amount of credit in the market. Rather, it chose to reallocate the credit in the market by providing loans to institutions that participated in its new lending programs, while offsetting the effect of this lending on total credit through open market operations.

Why the Fed chose this unconventional approach is also unclear. Bernanke (2008) seems to suggest that the desire was not to increase the total liquidity in the economy but to provide liquidity to banks and other institutions that had illiquid, but sound, assets so that these institutions would continue to lend for productive purposes and avoid the inefficient liquidation of assets that were temporarily illiquid. It is also likely that the Fed was concerned that a significant increase in total liquidity might impair its ability to keep the federal funds rate close to the FOMC's target. ${ }^{13}$

Whatever the reason, it now appears that the Fed has abandoned the strategy of offsetting completely the effects of it new lending programs. Indeed, the Fed has injected historically large amounts of credit into the market. Such massive injections of base money have raised concerns about accelerating inflation. However, provided the increase is temporary and is removed once the need for additional liquidity is gone, as the Fed did in Y2K and 9/11, there is no reason that a temporary increase in base money should cause the long-term inflation rate to increase.

\section{REFERENCES}

Allen, Franklin and Gale, Douglas. Understanding Financial Crises (Clarendon Lectures in Finance). Oxford: Oxford University Press, 2007.

Bernanke, Ben S. "Liquidity Provision by the Federal Reserve." Presented at the Federal Reserve Bank of Atlanta Financial Markets Conference, Sea Island, Georgia, May 13, 2008; www.federalreserve.gov/ newsevents/speech/bernanke20080513.htm.

Board of Governors of the Federal Reserve System. "Monetary Policy Report to the Congress."

\footnotetext{
${ }^{13}$ Keister, Martin, and McAndrews (2008) suggest that this is why the Fed chose not to increase the supply of total credit.
} 
February 27, 2008; www.federalreserve.gov/ boarddocs/hh/2008/february/fullreport.pdf.

Cecchetti, Stephen G. "Crisis and Responses: The Federal Reserve and the Financial Crisis of 20072008.” NBER Working Paper No. 14134, National Bureau of Economic Research, June 2008; www.nber.org/ papers/w14134.pdf.

Friedman, Milton and Schwartz, Anna J. A Monetary History of the United States, 1867-1960. Princeton, NJ: Princeton University Press, 1963.

Keister, Todd; Martin, Antoine and McAndrews, James. "Divorcing Money from Monetary Policy." Federal Reserve Bank of New York Economic Policy Review, September 2008, 14(2), pp. 41-56;

http://www.ny.frb.org/research/EPR/08v14n2/ 0809keis.pdf.

Meltzer, Allan. A History of the Federal Reserve, 1951-1986. Volume 2A. Chicago: University of Chicago Press, 2009 (forthcoming).

Modigliani, Franco and Sutch, Richard C. "Innovations in Interest Rate Policy." American Economic Review, May 1966, 56, pp. 178-97.

Neely, Christopher J. "The Federal Reserve Responds to Crises: September 11th Was Not the First." Federal Reserve Bank of St. Louis Review, March/April 2004, 86(2), pp. 27-42; http://research.stlouisfed.org/ publications/review/04/03/Neely.pdf.
Small, David H. and Clouse, James A. "The Scope of Monetary Policy Actions Authorized Under the Federal Reserve Act." Topics in Macroeconomics, 2005, 5(1), Article 6.

Taylor, John B. and Williams, John C. "A Black Swan in the Money Market." Forthcoming in American Economic Journal: Macroeconomics, 2008a; preview at www.aeaweb.org/aej/mac/accepted/ 2008-0048.pdf.

Taylor, John B. and Williams, John C. "Further Results on a Black Swan in the Money Market." Stanford University, unpublished manuscript, 2008b; www.stanford.edu/ johntayl/Taylor-WilliamsFurther\%20Results\%20on\%20Black\%20Swan.pdf.

Thornton, Daniel L. “The Federal Reserve’s Operating Procedures, Nonborrowed Reserves, Borrowed Reserves and the Liquidity Effect." Journal of Banking and Finance, 2001, 25(9), pp. 1717-39.

Thornton, Daniel L. "Walter Bagehot, the Discount Window, and TAF." Federal Reserve Bank of St. Louis Economic Synopses, 2008, no. 27; http://research.stlouisfed.org/publications/es/08/ ES0827.pdf. 
